\title{
“Am I Good Enough for You?" Features Related to Self-Perception and Self-Esteem of Brazilians from Different Socioeconomic Status
}

\author{
Anthonieta L. Mafra ${ }^{*}$, Fívia A. Lopes ${ }^{2}$ \\ ${ }^{1}$ Graduate Program in Psychobiology, Universidade Federal do Rio Grande do Norte [UFRN], Natal, Brazil \\ ${ }^{2}$ Graduate Program in Psychobiology, Department of Physiology, UFRN, Natal, Brazil \\ Email: "looman.anthonieta@gmail.com
}

Received 27 February 2014; revised 25 March 2014; accepted 21 April 2014

Copyright @ 2014 by authors and Scientific Research Publishing Inc.

This work is licensed under the Creative Commons Attribution International License (CC BY).

http://creativecommons.org/licenses/by/4.0/

(c) (i) Open Access

\begin{abstract}
Several studies have been conducted to expand our knowledge about human romantic relationships, mostly seeking to highlight the factors of greatest influence. However, much of these works were based on samples of university students, which affords certain limitations to drawing any conclusions about the general population, especially in countries where the rate of social inequality is high. The current study aims to address this limitation and determine whether there actually is a significant difference between self-esteem and self-perception as a potential romantic partner among samples of people from two different socioeconomic status (SES), based on data derived from 150 participants (64 of higher SES and 86 of lower SES) in northeastern Brazil. Our results confirm the existence of differences in self-esteem and self-perception as a romantic partner among people from different SES, underscoring the need for further exploration of non-university groups in the study of factors that influence romantic relationships.
\end{abstract}

\section{Keywords}

Self-Perception, Self-Esteem, Socioeconomic Level, Educational Level, Mate Preference

\section{Introduction}

The criteria for selecting romantic partners have been related to the type of investment that men and women

"Corresponding author.

How to cite this paper: Mafra, A. L., \& Lopes, F. A. (2014). "Am I Good Enough for You?" Features Related to Self-Perception and Self-Esteem of Brazilians from Different Socioeconomic Status. Psychology, 5, 653-663.

http://dx.doi.org/10.4236/psych.2014.57077 
make in their offspring, resulting in mate preference differences between the sexes (Buss, 1988; Buss \& Schmitt, 1993; Buunk, Dijkstra, Fetchenhauer, \& Kenrick, 2002; Castro, Hattori, \& Lopes, 2012; Fletcher, Tither, O’Loughlin, Friesen, \& Overall, 2004; Gaulin \& McBurney, 2001; Li \& Kenrick, 2006; Trivers, 1972). Men, for the most part, tend to give greatest importance to physical attractiveness (Buss \& Shackelford, 2008; Castro \& Lopes, 2011; Fisher, Cox, Bennett, \& Gavric, 2008; Hattori, Castro, \& Lopes, 2013; Pawlowski, 2000), since this characteristic provides clues about youthfulness and female fertility, which are indicators of good genes and the ability to bear children (Buss \& Shackelford, 2008; Castro et al., 2012; Castro \& Lopes, 2011; Gaulin \& McBurney, 2001; Goodwin, Marshall, Fülöp, Adonu, \& Spiewak, 2012; Gutierres, Kenrick, \& Partch, 1999; Hattori et al., 2013; Karremans, Frankenhuis, \& Arons, 2010; Pawlowski, 2000). In contrast, most women afford greater preference to resource ownership and/or characteristics that indicate the potential for social mobility (Brase \& Guy, 2004; Buss \& Shackelford, 2008; Castro et al., 2012; Castro \& Lopes, 2011; Fisher et al., 2008; Geary, Vigil, \& Byrd-Craven, 2004; Hattori et al., 2013; Pawlowski, 2000), such as intelligence and dedication to work, and the propensity of a man to invest in the family (Buss \& Shackelford, 2008; Goodwin et al., 2012). In this way, the investment of resources in family is considered the male domain, because women have a much greater physiological investment (through pregnancy and breastfeeding) and, in most cases, maternal care (Allen \& Bailey, 2007; Buss \& Schmitt, 1993; Geary et al., 2004, Gutierres et al., 1999; Kenrick, Sadalla, Groth, \& Trost, 1990; Kruger, Fitzgerald, \& Peterson, 2010; Pawlowski, 2000; Trivers, 1972).

Thus, there is a sound basis to compare preferences for investment in offspring. However, some factors may interfere at the time when real choices are made with respect to mate preferences, for example, the desired duration and investment in a relationship (Buss \& Schmitt, 1993; Castro \& Lopes, 2011). Yet, even at the time of choosing a romantic partner, there is still a need to reconcile mate preferences with what an individual actually has to offer as a potential partner (i.e. their market value). Market value, in this context, is described as an individual's ability to find, attract and keep a romantic partner, according to the availability and quality of existing competitors in a given environment (Fisher et al., 2008; Pawlowski, 2000). Accordingly, self-perception as a romantic partner is formed through an evaluation of one's own attractiveness in comparison to that of potential competitors (Goodwin et al., 2012). Thus, each sex tends to conduct its own self-perception according to what they know about the preferences of their opposite sex. According to Goodwin et al. (2012), physical attractiveness has greater weight in female self-perception, while characteristics that indicate financial resources and/or the ability to acquire them have greater weight in self-perception by males. Therefore, when considering the choice of a romantic partner, each individual modulates his or her own level of requirement for what to look for in a romantic partner according to what they believe they have to offer in exchange (Buston \& Emlen, 2003; Lee, Loewenstein, Ariely, Hong, \& Young, 2008).

In addition to considering the characteristics of potential competitors on self-perception, self-esteem may also have some influence on the outcome. Based on sociometer theory (Leary \& Baumeister, 2000 quoted by Bale \& Archer, 2013; Penke \& Denissen, 2008), self-esteem is a predictor of social rejection. Therefore, high levels of social rejection can result in a decreased sense of self-esteem (Bale \& Archer, 2013; Brase \& Guy, 2004; Penke \& Denissen, 2008). Bale and Archer (2013) and Wade (2000) believe that because physical attractiveness is an important feature for the market value of women and socioeconomic status (SES) and/or attributes that can facilitate access to resources are important for the male market value, self-esteem, like self-perception, should be affected in terms of traits that are perceived as being important to the market value of each sex.

Brazil is a large country with a high degree of social inequality, whereby people of the same age may have very different socioeconomic and educational backgrounds. Data from 2010, collected by the Brazilian Institute of Geography and Statistics (IBGE-Instituto Brasileiro de Geografia e Estatística [Brazilian Institute of Geography and Statistics]), indicate that $57.21 \%$ of the population earns up to a monthly minimum wage, currently set at R\$ 670.00 (US\$ 291.30), and 45.09\% do not have formal education or never completed school. In general, people from lesser financial backgrounds must study in public schools because they cannot afford to attend a private school and gain access to a better quality education. Public schools in Brazil are second worst in the global ranking of education according to the Economist (Prates, 2012), and in most cases, poorer children stop their studies prematurely in order to enter the workforce earlier as a means of survival and, in some cases, for the well-being of their whole family. On the other hand, students of higher SES are not required to stop their studies early in order to ensure their livelihoods and are able to invest all of their time in education, thus entering universities at a younger age and in much greater numbers overall, compared to individuals of lower financial status. This information is corroborated by IBGE (2010) data that was collected to assess the educational level 
of individuals from households with lower incomes, showing that $58.35 \%$ of them have either no education or never completed primary school, with only $1.59 \%$ having completed any sort of higher education. On the other hand, $55.10 \%$ of those individuals from households with more than five minimum wages (over R $\$ 3350.00$ or US\$ 1456.52), representing just 5.54\% of the population of Brazil, complete some sort of post secondary education.

Beyond high inequality of family income distribution (Gini Index equal to 51.9 according to CIA —Central Intelligence Agency, 2012), Melo (2005) and Santana (2010) argued that the inequality also has gender. Although there was a decrease in gender inequality in nineties, female unemployment rates are bigger, access to leadership positions are narrower and wage differences (with men earning higher wages) still exist, in addition to the high workload and low social protection suffered by women. Furthermore, according to Melo (2005) and Santana (2010), the most commonly found family model in Brazil is the traditional model (man as household head and woman looking after house and children), and even in those families in which woman is responsible for family maintenance, she is rarely seen as household head, leaving this role to the man, once the household head is the most authoritative person and imposes more respect. Gathering all the facts, men are the most responsible for supporting the family in Brazil, what can indicate that Brazilian women show preference for men who are able to provide the necessary resources to maintain the family. Therefore, men's self-perception and self-esteem can be influenced by SES, implying that men with low SES would have a tendency to lower selfperception and self-esteem than men with high SES.

Thereby, the main purpose of the study was to verify whether there was a difference in self-esteem and self-perception between men and women, as romantic partners, from different socioeconomic backgrounds, differing from researches that had used undergraduate samples (i.e. Bale \& Archer, 2013; Brase \& Guy, 2004; Castro \& Lopes, 2011; Castro et al., 2012; Fisher et al., 2008; Goodwin et al., 2012; Wade, 2000, 2003). Therefore, the sample was divided in four groups: high SES women, high SES men, low SES women and low SES men, men and women from different SES can be compared in order to verify if purchasing power influences how each gender perceives itself. Thereunto, the sample was composed of participants aged from 18 to around 30 years. Once the level of education is associated with the SES in Brazil, data from undergraduate and Elementary and High School (EHS) students were collected, the EHS representing the low SES sample and undergraduate students representing high SES sample. To make this assessment, four analyses were conducted and the predictions were based on Castro and Lopes (2011) findings for undergraduate students of the same Brazilian city in which data were collected. Castro and Lopes (2011) found that Brazilian undergraduate men gave more importance to physical traits in their partner to a short-term relationship and to physical and personal traits to a longterm relationship, and Brazilian undergraduate women gave more importance to physical and personal traits to a short-relationship, and to personal traits and to men's desire to acquire resources when involvement increases.

The first analysis aimed to identify how individuals of different SES were distributed in terms of the level of self-esteem they present, which in this study was characterized as high, medium or low self-esteem. In this analysis, it was expected to find that men and women are not equally distributed concerning self-esteem levels (Hypothesis 1). More men with higher SES would also present higher levels of self-esteem while more men with lower SES would possess relatively lower self-esteem, since this is related to male self-perception (Bale \& Archer, 2013; Fisher et al., 2008; Goodwind et al., 2012). On the contrary, this result was not expected for women, once socioeconomic differences should not influence their self-esteem because female self-esteem and self-perception are usually associated with physical attractiveness and not with their socioeconomic conditions (Bale \& Archer, 2013; Brase \& Guy, 2004; Wade, 2000).

In the second analysis, the study aimed to determine the importance of particular traits in self-perception. It was expected that women and men gave importance to different characteristics (Hypothesis 2): women would give greater importance to physical attractiveness when evaluating their overall desirability as a romantic partner, and that men would give more importance to their social status and/or features indicative of their ability to acquire resources in their own self-perception, regardless of socioeconomic background.

The third analysis was designed to assess if men and women were different in their self-perception according to SES. It was expected that SES affected women's and men's self-perception differently (Hypothesis 3); only men would present any differences in self-perception as indicators of good financial status are most commonly valued by women in choosing their romantic partners.

Finally, the fourth analysis examined whether there was indeed a relationship between self-perception and self-esteem and, if it existed, what characteristics of self-perception are related to self-esteem in each of the four 
groups of subjects. It was expected to find different traits related to women's self-esteem and men's self-esteem (Hypothesis 4). Here the prediction was that women would show a relationship between their self-esteem/ self-perception and physical attractiveness, and men with characteristics indicative of social status and earning potential.

\section{Methods}

\subsection{Study Site and Participants}

The current study was conducted in the city of Natal, in the state of Rio Grande do Norte, northeastern Brazil, and was based on a total of 150 participants: 64 individuals of the total sample size belonged to a higher SES (high SES), with 31 of these subjects being undergraduate women (22.93 \pm 3.04 years) and 33 being undergraduate men (21.94 \pm 3.19 years), while 86 individuals of the total sample size belonged to a lower SES (low SES), with 44 of these subjects being EHS women (23.97 \pm 6 years) and 42 EHS men (20.64 \pm 4.63 years).

\subsection{Sample Characterization}

According to the Brazilian skin color classification (IBGE, 2010), the total sample of study subjects was composed of $47 \%$ dark-skinned (mixed-race or pardo) people, 39.7\% white people, $7.9 \%$ black people and 5.2\% people with indigenous or Asian ancestry. An analysis to address the issues of socioeconomic characteristics showed that EHS public school students have, as a matter of fact, lower SES than university students. The majority of EHS students were level C1 for men (average family income of R\$1,541.00, equivalent to approximately US\$ 670.00) and level C2 for women (average family income of R\$ 1,024.00, equivalent to approximately US\$ 445.22), while university students were level B2 for both sexes (average family income of $\mathrm{R} \$ 2,565.00$, equivalent to approximately US\$1,115.22), according to the classification of Brazilian Association of Research Companies (Associação Brasileira de Empresas de Pesquisa (ABEP) [Brazilian Association of Research Companies], 2012).

\subsection{Procedure}

The sample consisted of undergraduate students from Universidade Federal do Rio Grande do Norte, enrolled in the following courses: Biological Science, Nursing, Medicine, Pharmacy, Ecology, Dentistry, Sciences and Technology, Psychology, and Chemical Engineering. At first, professors were asked if they could provide around 20 minutes of their class time for students to respond the questionnaire.

To collect data from EHS students, directors and coordinators were contacted from each one of the nine public schools in which the questionnaires were applied, and asked permission to access teachers, in order to apply the questionnaire with EHS students.

\subsection{Instruments}

Each participant answered a questionnaire that included: 1-matters of socioeconomic characteristics; 2-the Rosenberg self-esteem scale; 3-line of perceived sex ratio; and 4-self-perception as a potential romantic partner.

1) The matters of socioeconomic characteristics were used according to ABEP (2012) classification. The participants were instructed to mark one of five options (null, one, two, three, and four or more), representing the quantity of certain items (color televisions, DVD players, fridges, housemaids, bathrooms, automobiles, freezer, stereos, and washing machines) they had at home and to indicate the level of education of the household head.

2) The Rosenberg self-esteem scale (Rosenberg, 1989) consists of ten statements about the feelings and thoughts of an individual with respect to him- or herself, which were evaluated according to a 4-point Likert scale (ranging from strongly disagree to strongly agree). This scale was translated and adapted into Portuguese and validated for Brazilian population with Cronbach alpha value of 0.9 (Hutz \& Zanon, 2011).

3) The line of perceived sex ratio is an assessment of semantic differential with 10 centimeters. Participants were supposed to mark on the line their perception of the proportion of men and woman available to be a romantic partner ranging from more women than men (0) to more men than women (10).

4) In the space for self-perception, each person was supposed to evaluate itself according to nine characteristics: three related to physical attractiveness (Pretty face, Beautiful body, and Health), three related to resources 
and/or ability to acquire it (Determined and hardworking, Good financial condition, and Intelligent), and three traits related to personality (Sociable, Agreeableness, and Loyal). For each characteristic the participant could assign 0 - 9 points. More points indicated that the subject thought he or she had more of such characteristic. There was also a 10 centimeters line in which each participant was asked to evaluate their general desirability by making at any point corresponding to how desirability as romantic partner they consider themselves to be, ranging from not desirable (0) to extremely desirable (10).

\subsection{Analyses}

The results were significant for the Kolmogorov-Smirnov normality test and not significant for Levene's test of homogeneity, indicating non-normality of the sample and its homogeneity. Considering this result, parametric tests were used for subsequent analyses, with the exception of the Chi-square test, which used to determine the distribution of levels of self-esteem in our population (Analysis 1), for each of the four groups studied: low SES men, high SES men, low SES women and high SES women. To check which characteristics are predictors of desirability as a romantic partner in men and women from two different SES (Analysis 2), a linear regression analysis of the enter type was made for self-perception, using the general desirability of self-perception as the dependent variable and the nine features listed above as independent variables.

For the third analysis, measures of self-esteem, of the characteristics and overall desirability of individual self-perception of the two different SES were compared for each sex, using the Student's t-test. Lastly, Pearson's linear correlation coefficient was used to verify the existence of any correlation between self-esteem and each of the nine characteristics and overall desirability (Analysis 4) for each sex according to SES.

To interpret the strength of correlations, Dancey and Reidy (2006) parameters were used, which consider perfect correlations to be where $r=1$; strong correlations where $r$ is between 0.7 and 0.9 , moderate where $r$ is between 0.4 to 0.6 , and weak where $r$ is less than 0.3 .

All statistical tests were carried out at a 95\% confidence level.

\section{Results}

\subsection{Distribution of Self-Esteem}

The Chi-square analysis indicated how individuals from different SES were distributed in terms of level of self-esteem presented. The results did not confirm our predictions that women distributed equally among the levels of self-esteem while men did not. Men are equally distributed among the levels of self-esteem, regardless of their SES $\left(\chi^{2}=.452, p=.798\right.$ ) (Table 1$)$. However, more low SES women were classified as having low self-esteem and fewer with high self-esteem from the same group. High SES women were distributed oppositely, with more women classified as having high self-esteem and fewer women with low self-esteem $\left(\chi^{2}=6.451, p\right.$ $=.040$ ) (Table 1). The distribution of female participants classified as having medium levels of self-esteem mean was equal for both SES.

\subsection{Predictive Characteristics of General Attractiveness}

In order to determine the importance of particular traits in self-perception, a linear regression was made. The results were not as expected (women would give greater importance to physical attractiveness, while men would give more importance to characteristics related to resources in their own self-perception, regardless of SES). It was observed that, for low SES men and women, SES is a factor that affects subjects' self-perception.

No single characteristic was predictive of overall attractiveness in the self-perception of low SES women ( $\mathrm{F}(9$, $\left.32)=1.131, p=.371, \mathrm{R}=.497, \mathrm{R}^{2}=.247\right)$; for high SES women the characteristic Beautiful body was most predictive $\left(\mathrm{F}(9,19)=4.183, p=.004, \mathrm{R}=.815, \mathrm{R}^{2}=.665\right)$. For men, the characteristics that best explained overall desirability in their self-perception as romantic partners were: Pretty face and Sociable $(F(9,29)=2.519$, $\left.p=.029, \mathrm{R}=.662, \mathrm{R}^{2}=.439\right)$ and Determined and hardworking $\left(\mathrm{F}(9,22)=4.729, p=.001, \mathrm{R}=.812, \mathrm{R}^{2}=.659\right)$ for low and high SES, respectively.

\subsection{Comparison of Low SES and High SES}

In comparing self-perceptions to assess if men and women were different in their self-perception according to 
SES, the expectations that only men would present any differences in self-perception were not confirmed. High SES women gave more importance to: Good financial condition, Sociable, Intelligent and Loyal, compared to low SES women. For male self-perception, the university group (high SES) assigned higher scores to the characteristic Loyal, compared to low SES men, which assigned higher scores to their overall desirability (Table 2).

\subsection{Self-Esteem and Self-Perception}

In order to verify the existence of any correlation between self-esteem and each of the nine characteristics and overall desirability for each sex according to SES, Pearson's correlations were done and the results partially support our predictions. A relationship between their self-esteem/self-perception and some characteristics was found but not exactly the predicted ones.

Table 1. Results of the Chi-square test for distribution of self-esteem for low SES and high SES women and for low SES and high SES men.

\begin{tabular}{|c|c|c|c|c|c|}
\hline \multirow[b]{2}{*}{ Sex } & \multirow[b]{2}{*}{ SES } & & \multicolumn{3}{|c|}{ Self-esteem } \\
\hline & & & High & Normal & Low \\
\hline \multirow{6}{*}{ Women } & \multirow{3}{*}{ Low } & Observed & 5 & 33 & 6 \\
\hline & & Expected & 7.6 & 32.9 & 3.5 \\
\hline & & Residual & -2.6 & .1 & 2.5 \\
\hline & \multirow{3}{*}{ High } & Observed & 8 & 23 & 0 \\
\hline & & Expected & 5.4 & 23.1 & 2.5 \\
\hline & & Residual & 2.6 & -.1 & -2.5 \\
\hline \multirow{6}{*}{ Men } & \multirow{3}{*}{ Low } & Observed & 11 & 24 & 4 \\
\hline & & Expected & 10.3 & 23.8 & 4.9 \\
\hline & & Residual & .7 & .2 & -.9 \\
\hline & \multirow{3}{*}{ High } & Observed & 8 & 20 & 5 \\
\hline & & Expected & 8.7 & 20.2 & 4.1 \\
\hline & & Residual & -.7 & -.2 & -.9 \\
\hline
\end{tabular}

SES: Socioeconomic status.

Table 2. Results for comparisons of studied features, for men and women, according to SES.

\begin{tabular}{|c|c|c|c|c|c|c|c|}
\hline Sex & Features & SES & $\mathrm{N}$ & Mean & Standard Deviation & $t$ & $p$ \\
\hline \multicolumn{8}{|c|}{ Women } \\
\hline & \multirow{2}{*}{ Good financial condition } & Low & 44 & 3.55 & 2.017 & \multirow{2}{*}{-2.619} & \multirow{2}{*}{.011} \\
\hline & & High & 31 & $4.65^{*}$ & 1.404 & & \\
\hline & \multirow{2}{*}{ Sociable } & Low & 44 & 5.68 & 2.604 & \multirow{2}{*}{-2.050} & \multirow{2}{*}{.044} \\
\hline & & High & 31 & $6.77 *$ & 1.687 & & \\
\hline & \multirow{2}{*}{ Intelligent } & Low & 44 & .30 & 2.163 & \multirow{2}{*}{-3.548} & \multirow{2}{*}{.001} \\
\hline & & High & 30 & $6.83^{*}$ & 1.177 & & \\
\hline & \multirow{2}{*}{ Loyal } & Low & 44 & 7.48 & 2.492 & \multirow{2}{*}{-2.090} & \multirow{2}{*}{.040} \\
\hline & & High & 31 & $8.45^{*}$ & .850 & & \\
\hline \multicolumn{8}{|l|}{ Men } \\
\hline & \multirow{2}{*}{ Loyal } & Low & 42 & 6.40 & 2.669 & \multirow{2}{*}{-2.084} & \multirow{2}{*}{.041} \\
\hline & & High & 32 & $7.53^{*}$ & 1.704 & & \\
\hline & \multirow{2}{*}{ Overall desirability } & Low & 39 & $63.67^{*}$ & 21.140 & \multirow{2}{*}{2.089} & \multirow{2}{*}{.040} \\
\hline & & High & 33 & 54.24 & 16.288 & & \\
\hline
\end{tabular}

There are represented only the features those were significantly different between the two SES (Socioeconomic status) to women and men. *: Significantly higher means. 
A positive correlation was observed between the levels of self-esteem and overall desirability in self-perceptions of men from both SES ( $r=.412, p=.013$ for low SES, and $r=.526, p=.002$ for high SES), as well as for high SES women $(r=.405, p=.026)$. Therefore, when the level of self-esteem was higher, greater values were obtained in self-perceptions, except for low SES women, in which there was no detectable correlation between the two variables $(r=.101, p=.535)$.

Relating self-esteem to the different characteristics of self-perception, it was observed that low SES women, who had not shown any previous correlation between self-esteem and overall desirability, did show a correlation between self-esteem and the characteristics Pretty face and Intelligent $(r=.314, p=.04$, and $r=.491 ; p=.001$, respectively), indicating that the greater their self-esteem, the more value they attributed to these characteristics. For high SES women there was a positive correlation between the feature Pretty face and self-esteem $(r=.422$, $p=.018$ ). For high SES men, a correlation was found between self-esteem and Pretty face, Beautiful body and Intelligent ( $r=.413, p=.019, r=.376, p=.034$ and $r=.376, p=.002$ respectively), while in low SES men, self-esteem correlated with Pretty face ${ }_{1}$, Beautiful body $_{2}$, Health ${ }_{3}$, Good financial condition ${ }_{4}$, Sociable ${ }_{5}$, Determined and hardworking, Intelligent, Agreeableness $8\left(r_{1}=.471, p_{1}=.002, r_{2}=.498, p_{2}=.008, r_{3}=.434, p_{3}\right.$, $=.006 r_{4}=.419, p_{4},=.002 r_{5}=.484, p_{5}=.002 r_{6}=.469, p_{6}=.003, r_{7}=.453, p_{7},=.004$ and $\left.r_{8}=.346, p_{8}=.031\right)$.

\section{Discussion}

Considering that, in self-perception, the most valued characteristics are those most sought after in a romantic partner, individuals tend to give more importance to such features when they perform their own self-perception (Buston \& Emlen, 2003; Gutierres et al., 1999). As self-perception commonly has a positive relationship with self-esteem, traits that increase one's value in the mating market of each sex become associated not only with self-perception, but with self-esteem as well.

Characteristics indicative of physical attractiveness (represented in this study by Pretty face, Beautiful body and Health) are highly valued in choosing romantic partners. Men, in general, give great importance to these characteristics in a potential partner, because in addition to providing accurate clues about good quality genes and physiology, they provide information about female youthfulness (a limiting factor in assessing market value due to the shorter female reproductive period, compared to males) (Buston \& Emlen, 2003; Castro et al., 2012; Castro \& Lopes, 2011; Gaulin \& McBurney, 2001; Gutierres et al., 1999; Karremans et al., 2010; Pawlowski, 2000; Wade, 2000, 2003).

Although women do not give the same degree of importance to physical attractiveness in mate choice as men do, they do not ignore these characteristics entirely, since they may be related to other desirable traits such as dominance, competitive ability, social status, health and other variables that are relevant to an individual's potential level of parental investment (Bale \& Archer, 2013; Wade, 2000, 2003). These characteristics are of great importance due to the high level of female investment in offspring, leaving the man with a more important role in investing resources. Thus, characteristics indicative of access to resources (represented in this study by Good financial condition) or that provide accurate clues about the ability and potential of an individual to acquire resources (represented in this study by Intelligent and Determined and hardworking) are of paramount importance in choosing a romantic partner (Buston \& Emlen, 2003; Castro et al., 2012; Geary et al., 2004; Gutierres et al., 1999; Kruger et al., 2010), especially in a long-term relationship where the possibility of producing offspring is greater. Features like Agreeableness and Sociable can be indicative of a person's potential for social mobility (since most sociable people have a better chance of increasing their social status, and may therefore be an indicator of potential to acquire resources) and may indicate the likelihood of forming a good quality relationship (Castro \& Lopes, 2011; Fletcher et al., 2004). Along with these characteristics, Loyal is also indicative of an individual's potential for having a good quality relationship, particularly in the sense of offering men greater assurance about the paternity of their children (Gaulin \& McBurney, 2001; Pawlowski, 2000; Trivers, 1972), and giving women greater assurance about the level of invest in their offspring that can be expected from a potential partner (Gaulin \& McBurney, 2001), giving this characteristic even greater value in mate choice.

According to these conclusions, our work is consistent with much of the data discussed in the literature, showing that the characteristics assessed here are associated with female and/or male self-esteem and self-perception, and largely in the ways predicted by parental investment theory (Trivers, 1972). However, certain peculiarities can be observed in this sample.

For instance, low SES men showed a positive relationship between self-esteem and self-perception as a ro- 
mantic partner for all the characteristics analyzed except Loyal. Considering that all the characteristics are important in choosing a romantic partner, it is important to understand why only loyalty was not considered important to the self-esteem of these men. Analyzing the operational reason perceived by participants, it was found that low SES men believed that there are more women than men available in the mating market $(\mathrm{M}=2.72$, or 145.56 women for 100 men), followed by high SES men ( $\mathrm{M}=2.91$, or 141.82 women for 100 men) and high SES women ( $M=3.47$, or 130.58 women for 100 men). Low SES women believed that the number of men and women available in the mating market is nearly equal ( $\mathrm{M}=4.86$, or 102.76 women for 100 men). Thus, perceptions of sex ratio appear to be another factor that can influence the characteristics considered to be most important in a romantic partner, especially with respect to characteristics that limit the quantity of an individual's romantic partners.

High SES women attributed more value to the characteristics Good financial condition and Intelligent in their self-perception, among others. According to the characterization of the sample, high SES women have, in fact, better financial conditions than low SES women (R \$ 2565.00 or US\$ 1115.22 and R\$ 1024.00 and US\$ 445.22, respectively), while Intelligent, the difference in value afforded to this character between the two groups is probably due to their respective differences in the level of education achieved, such that high SES women (university students) awarded more points to this trait in their self-perception, compared to low SES women (EHS students).

Looking deeper into the group of low SES women, the characteristic Intelligent was positively associated with self-esteem. However, such a feature, as an indicator of the ability to acquire resources, is often positively related to self-esteem (Bale \& Archer, 2013) and self-perception in men (Buston \& Emlen, 2003; Gutierres et al., 1999), being largely considered a peculiarity of female self-esteem until now. However, along with the fact that these women have the lowest SES of the four groups, the ability to acquire resources should be important not only in finding a partner that can contribute to the family income, but also in ensuring one's own survival. Corroborating these assumptions, Lippa (2007) suggested that in a society where women contribute to family income, men tend to assign greater value to the intelligence of a potential partner, justifying the observation in the current study, that this characteristic is associated with female self-esteem.

Some studies focusing on samples of non-university individuals have also found that results may differ from the patterns reported in the literature and more closely approach observations of the present study. Moore, Cassidy, Law Smith, and Perrett (2006), for example, found that when women themselves have access to sufficient resources to care for their children, their preferences for physical attractiveness increase. Pillsworth (2008), in his work with the Shuar people of Ecuador predicted results similar to those observed by Moore et al. (2006). The livelihoods of Shuar villagers are based on hunting and gathering. While the men are responsible for hunting larger animals, the women are responsible for horticulture, collecting larvae and fruits, fishing and hunting small animals. In this context, and according to the predictions of Pillsworth, women should show an increased preference for physical attractiveness in mate choice, given the magnitude of their own contributions to family resources. However, the results of this study pointed in another direction, that is, both men and women in this particular group give greatest value to characteristics related to the ability to acquire resources, compared to physical attractiveness. The results of Pillsworth (2008) corroborate our findings that men of lower SES and/or education, as a matter of fact, prefer women that contribute to family income and, therefore, characteristics indicating the ability to acquire resources weigh more in the self-perceptions of low SES women than they do for high SES women.

Low SES women also showed no positive relationship between self-esteem and overall desirability, while the other three groups did so, lending more evidence to the idea that low SES women do not analyze their self-esteem in the same way. Furthermore, supporting this conclusion further, in checking whether SES influences how individuals are distributed in terms of their levels of self-esteem, most low SES women had low self-esteem compared to high SES women.

\section{Conclusion}

Although previous studies have shown certain patterns in mate choice for men and women, the samples were mostly of university students, which may well be a good representation of the general population in more developed countries (London, Portugal, Poland, Spain [Goodwin et al., 2012]; USA [Brase \& Guy, 2004]; Canada [Fisher et al., 2008]). However in countries with high levels of social inequality, such a sample cannot be consi- 
dered as an accurate representation of the general population. Indeed, this research presented here shows that there are significant differences in how men and women evaluate potential romantic partners according to their level of education, which is directly related to SES in Brazil. For women, there was a notable difference in selfesteem and self-perception, possibly marked by educational and SES, providing new data for the study of mate preferences, since this pattern is typically observed in males. Additional studies including people of different educational and SES are needed to better understand the factors that influence self-perception as a romantic partner in order to better understand the dynamics of the mating market in our species.

\section{Acknowledgements}

This research was supported by Coordenação de Aperfeiçoamento de Pessoal do Nível Superior (CAPES) awarded to Anthonieta L. Mafra and by Conselho Nacional de Desenvolvimento Científico e Tecnológico (CNPq) awarded to Fívia de Araújo Lopes (nº 409111/2013-9).

We thank CNPq ( $n^{\circ}$ 409111/2013-9) and CAPES for supporting the development of the research; we thank the participants who agreed to complete the questionnaire, mainly considering that the research was voluntary and without financial and/or material return; we also thank professors and teachers as well as the schools' directors for making their classes available for the data collection; and we thank especially Felipe N. Castro for providing us his questionnaire, from which we based on part of our questionnaire.

\section{References}

Associação Brasileira de Empresas de Pesquisa (ABEP) [Brazilian Association of Research Companies] (2012). Dados com base no levantamento socioeconômico de 2010 [Data based on 2010 socioeconomic survey]—IBOPE. www.abep.org

Allen, S., \& Bailey, K. (2007). Are Mating Strategies and Mating Tactics Independent Constructs? Journal of Sex Research, 44, 225-232. http://dx.doi.org/10.1080/00224490701443601

Bale, C., \& Archer, J. (2013). Self-Perceived Attractiveness, Romantic Desirability and Self-Esteem: A Mating Sociometer Perspective. Evolutionary Psychology, 11, 68-84.

Brase, G. L., \& Guy, E. C. (2004). The Demographics of Mate Value and Self-Esteem. Personality and Individual Differences, 36, 471-484. http://dx.doi.org/10.1016/S0191-8869(03)00117-X

Buss, D. M. (1988). The Evolution of Human Intrasexual Competition: Tactics of Mate Attraction. Journal of Personality and Social Psychology, 54, 616-628. http://dx.doi.org/10.1037/0022-3514.54.4.616

Buss, D. M., \& Schmitt, D. P. (1993). Sexual Strategies Theory: An Evolutionary Perspective on Human Mating. Psychological Review, 100, 204-232. http://dx.doi.org/10.1037/0033-295X.100.2.204

Buss, D. M., \& Shackelford, T. K. (2008). Attractive Women Want It All: Good Genes, Economic Investment, Parenting Proclivities, and Emotional Commitment. Evolutionary Psychology, 6, 134-146.

Buston, P., \& Emlen, S. (2003). Cognitive Processes Underlying Human Mate Choice: The Relationship between Self-Perception and Mate Preference in Western Society. Proceedings of the National Academy of Sciences, 100, 8805-8810. http://dx.doi.org/10.1073/pnas.1533220100

Buunk, B. P., Dijkstra, P., Fetchenhauer, D., \& Kenrick, D. T. (2002). Age and Gender Differences in Mate Selection Criteria for Various Involvement Levels. Personal Relationship, 9, 271-278. http://dx.doi.org/10.1111/1475-6811.00018

Castro, F. N., \& Lopes, F. A. (2011). Romantic Preference in Brazilian Undergraduate Students: From the Short Term to the Long Term. Journal of Sex Research, 47, 1-7. http://dx.doi.org/10.1080/00224499.2010.506680

Castro, F. N., Hattori, W. T., \& Lopes, F. A. (2012). Relationship Maintenance or Preference Satisfaction? Male and Female Strategies in Romantic Partner Choice. Journal of Social, Evolutionary, and Cultural Psychology, 6, 217-226.

http://dx.doi.org/10.1037/h0099213

Central Intelligence Agency (CIA) (2012). The World Factbook. https://www.cia.gov/library/publications/the-world-factbook/geos/br.html

Dancey, C., \& Reidy, J. (2006). Estatística sem matemática para psicologia: Usando SPSS para Windows [Statistics without maths for psychology: Using SPSS for Windows]. Porto Alegre: Artmed.

Fisher, M., Cox, A., Bennett, S., \& Gavric, D. (2008). Components of Self-Perceived Mate Value. Special Issue: Proceedings of the 2nd Annual Meeting of the North-Eastern Evolutionary Psychology Society. Journal of Social, Evolutionary, and Cultural Psychology, 2, 156-168. http://dx.doi.org/10.1037/h0099347

Fletcher, G. J., Tither, J. M., O’Loughlin, C., Friesen, M., \& Overall, N. (2004). Warm and Homely or Cold and Beautiful? Sex Differences in Trading off Traits in Mate Selection. Personality and Social Psychology Bulletin, 30, 659-672. 
http://dx.doi.org/10.1177/0146167203262847

Gaulin, S. J., \& McBurney, H. D. (2001). Chapter 10: The Psychology of Human Mating. In S. J. Gaulin, \& H. D. McBurney (Eds.), Psychology: An Evolution Approach. New Jersey: Prentice Hall.

Geary, D., Vigil, J., \& Byrd-Craven, J. (2004). Evolution of Human Mate Choice. Journal of Sex Research, 41, $27-42$. http://dx.doi.org/10.1080/00224490409552211

Goodwin, R., Marshall, T., Fülöp, M., Adonu, J., \& Spiewak, S. (2012). Mate Value and Self-Esteem: Evidence from Eight Cultural Groups. PLoS ONE, 7, Article ID: e36106. http://dx.doi.org/10.1371/journal.pone.0036106

Gutierres, S., Kenrick, D., \& Partch, J. (1999). Beauty, Dominance, and the Mating Game: Contrast Effects in Self-Assessment Reflect Gender Differences in Mate Selection. Personality and Social Psychology Bulletin, 25, 1126-1134. http://dx.doi.org/10.1177/01461672992512006

Hattori, W. T., Castro, F. N., \& Lopes, F. A. (2013). Mate Choice in Adolescence: Idealizing Romantic Partners. Psico (PUCRS), 44, 226-234.

Hutz, C. S., \& Zanon, C. (2011). Revisão da adaptação, validação e normatização da escala de autoestima de Rosenberg. Avaliação Psicológica [Review of the Adaptation, Validation, and Standardization of Rosenberg Self-Esteem Scale. Psychological Assessment], 10, 41-49.

Instituto Brasileiro de Geografia e Estatística (IBGE) (2010). Síntese de indicadores sociais: Uma análise das condições de vida da população Brasileira, Estudos \& pesquisas: Informação demográfica e socioeconômica [Synthesis of Social Indicators: An Analysis of the Living Conditions of the Brazilian Population. Studies \& Surveys: Demographic and Socioeconomic Information]. Rio de Janeiro: Author (Número 27).

Karremans, J., Frankenhuis, W., \& Arons, S. (2010). Blind Men Prefer a Low Waist-to-Hip Ratio. Evolution and Human Behavior, 31, 182-186. http://dx.doi.org/10.1016/j.evolhumbehav.2009.10.001

Kenrick, D. T., Sadalla, E. K., Groth, G., \& Trost, M. R. (1990). Evolution, Traits, and the Stages of Human Courtship: Qualifying the Parental Investment Model. Journal of Personality, 58, 97-116. http://dx.doi.org/10.1111/j.1467-6494.1990.tb00909.x

Kruger, D., Fitzgerald, C., \& Peterson, T. (2010). Female Scarcity Reduces Women’s Marital Ages and Increases Variance in Men’s Marital Ages. Evolutionary Psychology, 8, 420-431.

Lee, L., Loewenstein, G., Ariely, D., Hong, J., \& Young, J. (2008). If I’m Not Hot, Are You Hot or Not?-Physical Attractiveness Evaluations and Dating Preferences as a Function of One's Own Attractiveness. Psychological Science, 19, 669-677. http://dx.doi.org/10.1111/j.1467-9280.2008.02141.x

Li, N. P., \& Kenrick, D. T. (2006). Sex Similarities and Differences in Preferences for Short-Term Mates: What, Whether, and Why. Journal of Personality and Social Psychology, 90, 468-489. http://dx.doi.org/10.1037/0022-3514.90.3.468

Lippa, R. A. (2007). The Preferred Traits of Mates in a Cross-National Study of Heterosexual and Homosexual Men and Women: An Examination of Biological and Cultural Influences. Archives of Sexual Behavior, 36, 193-208. http://dx.doi.org/10.1007/s10508-006-9151-2

Melo, H. P. (2005). Gênero e pobreza no Brasil. Relatório Final do Projeto Governabilidad Democratica de Género en America Latina y el Caribe. [Gender and Poverty in Brazil. Final Project Reporty Gender Democratic Governance in Latin America and the Caribbean]. Brasília: CEPAL, SPM.

Moore, F. R., Cassidy, C., Law Smith, M. J., \& Perrett, D. I. (2006). The Effects of Female Control of Resources on Sex-Differentiated Mate Preferences. Evolution \& Human Behavior, 27, $193-205$. http://dx.doi.org/10.1016/j.evolhumbehav.2005.08.003

Pawlowski, B. (2000). The Biological Meaning of Preferences on the Human Mate Market. Anthropological Review, 63, 39-72.

Penke, L., \& Denissen, J. (2008). Sex Differences and Lifestyle-Dependent Shifts in the Attunement of Self-Esteem to Self-Perceived Mate Value: Hints to an Adaptive Mechanism? Journal of Research in Personality, 42, 1123-1129. http://dx.doi.org/10.1016/j.jrp.2008.02.003

Pillsworth, E. G. (2008). Mate Preferences among the Shuar of Ecuador: Trait Rankings and Peer Evaluations. Evolution and Human Behavior, 29, 256-267. http://dx.doi.org/10.1016/j.evolhumbehav.2008.01.005

Prates, M. (2012). Brasil tem a $2^{\text {a }}$ pior educação em ranking global da Economist [Brazil Has the Second Worst Education in Global Ranking of Economist]. Exame.com.

http://exame.abril.com.br/brasil/noticias/brasil-tem-2a-pior-educacao-em-ranking-global-da-economist

Rosenberg, M. (1989). Society and the Adolescent Self-Image. Revised Edition. Middletown, CT: Wesleyan University Press.

Santana, A. M. (2010). Mulher mantenedora/homem chefe de família: Uma questão de gênero e poder [Woman Sponsor/ Man Household Head: A Question of Gender and Power]. Forum Identities Magazine, 4, 71-87. 
Trivers, R. (1972). Parental Investment and Sexual Selection. In B. Campbell (Ed.), Sexual Selection and the Descent of Man (pp. 136-179). Chicago: Aldine-Atherton.

Wade, T. J. (2000). Evolutionary Theory and Self-Perception: Sex Differences in Body Esteem Predictors of Self-Perceived Physical and Sexual Attractiveness and Self-Esteem. International Journal of Psychology, 35, 36-45. http://dx.doi.org/10.1080/002075900399501

Wade, T. J. (2003). Evolutionary Theory and African American Self-Perception: Sex Differences in Body-Esteem Predictors of Self-Perceived Physical and Sexual Attractiveness, and Self-Esteem. Journal of Black Psychology, 29, 123-141. 